\title{
ASSESSMENT OF ESTROGEN RECEPTOR GENE POLYMORPHISM (T-397C VARIANT) IN PATIENTS WITH PREMENSTRUAL SYNDROME
}

DOI: 10.36740/WLek202007136

\author{
Lyudmyla V. Pakharenko, Volodymyr D. Vorobii, Nataliia Ya. Kurtash, Olena M. Kusa, Inna V. Kravchuk, \\ Viktor M. Zhurakivskyi \\ IVANO-FRANKIVSK NATIONAL MEDICAL UNIVERSITY, IVANO-FRANKIVSK, UKRAINE
}

\begin{abstract}
The aim: of the study is to determine the frequency of polymorphism of estrogen receptor gene ESR1 (T-397C variant) in patients with premenstrual syndrome.

Materials and methods: 50 women with diagnosis of premenstrual syndrome (the basic group) and 25 persons without it (the control group) were examined. Polymerase chain reaction was used to study T-397C polymorphism of estrogen receptor gene ESR1.

Results: There was no significant difference in allele and genotype rates of ESR1 gene between persons with premenstrual syndrome and controls. TT genotype was determined in $24.0 \%$ women in the control group and $24 \%$ of patients in basic group $(0 \mathrm{R}=1.00,95 \% \mathrm{Cl}=0.32-3.08, \mathrm{p}=1.00)$, TC genotype - in $52.0 \%$ and $46.0 \%$ of individuals respectively $(0 R=0.79,95 \% \mathrm{Cl}=0.30-2.06, \mathrm{p}=0.62), \mathrm{CC}$ genotype $-24.0 \%$ and $30.0 \%$ of women respectively $(0 \mathrm{R}=1.36,95 \% \mathrm{Cl}=0.45-4.07, \mathrm{p}=0.59)$. Also, the frequency of T allele and C allele was similar in individuals with pathology and healthy women. There was no significant difference in allele and genotype rates of T-397C variant of ESR1 gene between patients with mild and severe forms of premenstrual syndrome and controls.
\end{abstract}

Conclusions: There is no association of T-397C polymorphic variant of estrogen receptor gene ESR1 with the development of premenstrual syndrome.

KEY WORDS: premenstrual syndrome, estrogen receptor, polymorphism

Wiad Lek. 2020;73(7):1505-1509

\section{INTRODUCTION}

Premenstrual syndrome (PMS) is a common neuroendocrine syndrome in gynecology. $95 \%$ of women of reproductive age suffer from this pathology, these data differ and depend on the population, ethnic group, age, used diagnostic criteria [1]. The complex of numerous physical and psychological symptoms which occur in the second phase of the menstrual cycle and lead to daily functional impairment composes PMS. Stress load, poor physical activity, smoking, alcohol contribute to the forming of PMS [2]. The decline of quality of life - decreased daily and professional activities are usually observed in women with this disease [3]. Thus, PMS can be considered as the biopsychological pathology [4].

Different pathogenetic mechanisms are described to explain all clinical manifestations of PMS. The changes of estrogens and progesterone (its metabolites) levels during the menstrual cycle often lead to clinical signs of the syndrome. Besides this, these hormones considered to be as neuromediators and significantly affect mood changes [5] that can cause psychological manifestations of the pathology. In addition, the role of serotoninergic regulation, renin-angiotensin system are important in the development of PMS. Genetic aspects of PMS development are less studied. Certainly, family history has the important meaning. The significance of gene polymorphism is not established well. Nowadays the role of serotonin transporter gene polymorphism in the genesis of premenstrual dysphoric disorder was demonstrated [6].

\section{THE AIM}

The aim of the study is to determine the frequency of T-397C polymorphism of estrogen receptor gene ESR1 in patients with PMS.

\section{MATERIALS AND METHODS}

The study included 50 women with the diagnosis of PMS who formed the basic group, 25 of them had mild form of PMS and 25 - severe one. 25 women without this pathology were controls. The research was carried out in Ivano-Frankivsk City Clinical Perinatal Centre (Ukraine). Diagnosis of PMS was exhibited by the presence of cyclical manifestations of the disease in the luteal phase of menstrual cycle on the basis of history-taking and the results of patient's self-observation diary for 2-3 menstrual cycles (R. Moos Menstrual Distress Questionnaire). Mild PMS considered as the presence of 3-4 symptoms in 2-10 days before menstruation with significant severity 1-2 of them, severe form - the existence of 5-12 symptoms in 3-14 days before menstruation, 3-4 of them are most pronounced [7]. 
Inclusion criteria: reproductive age (18-44 years), regular menstrual cycle, presence of PMS, written consent from the patient. Exclusion criteria: pregnancy, lactation, disorders of menstrual cycle, focal lesions of breast, abnormal uterine bleeding of unknown etiology, acute inflammation of pelvic organs, tumors of uterus and ovaries of unknown etiology, endometrial hyperplasia, genital endometriosis, severe somatic pathology in the history, organic pathology of the central nervous system, mental illness, hormonal tumors, diabetes mellitus, adrenal diseases, thyroid pathology, malignant tumors in the present or in anamnesis, premenstrual dysphoric disorder, women who took psychotropic medications or hormonal therapy within the last three months.

Polymorphism of the genes was determined in the research laboratory of the Department of Medical Genetics, Shupyk National Medical Academy of Postgraduate Education (Kyiv). Material for the study was peripheral blood, which was collected into tubes with ethylenediaminetetraacetic acid in amount of $2.7 \mathrm{ml}$, Then deoxyribonucleic acid was extracted from samples of peripheral blood using commercial set “ДНК-сорб-В” (Central Research Institute of Epidemiology, Russia) according to the instruction. Polymerase chain reaction was done by "Fermentas" reagents (Lithuania) in the thermocycler «FlexCycler» (Analytik Jena, Germany). Restriction fragment length polymorphism was performed after polymerase chain reaction for study T-397C variant of ESR1 gene. The amplification products of the T-397C fragments were hydrolytically digested using the restriction endonuclease PvuII. The results of the restriction fragment length polymorphism were taken into account by conducting the electrophoresis of the resulting fragments in $2 \%$ agarose gel (Fermentas agarose) with the addition of ethidium bromide and subsequent visualization using the Vitran computer system.

For statistical analysis we used program Statistica 6.0. We calculated arithmetic mean value, average standard error, criterion $\chi^{2}$ (Yates corrected Chi-square), odds ratio (OR), confidence interval (CI). The nonparametric Mann-Whitney test was used to compare two independent groups by a single feature. The difference between the values that were compared was considered significant by $\mathrm{p} \leq 0.05$.

\section{RESULTS}

The average age of the persons in the control group was $27.16 \pm 1.09$ years, the basic one $-29.42 \pm 0.84$ years. Menarche started approximately in equal age of women in both groups $-13.04 \pm 0.2012 .94 \pm 0.12$ years respectively. The rate of gynecological pathology was also high in two groups - $21(84.0 \%)$ controls and $46(92.0 \%)$ patients with PMS. Most of the persons in the basic group had the combination of two-three gynecological diseases in anamnesis. Thus, inflammatory processes of appendages were diagnosed in 1.4 times more often (42 persons $(84.0 \%)$ ) than in healthy individuals ( 15 women $(60.0 \%) ; \chi^{2}=4.03$, $\mathrm{p}=0.045 ; \mathrm{OR}=3.50,95 \%$ CI 1.16-10.52, $\mathrm{p}=0.03)$, especially in patients with severe PMS (22 women $(88.0 \%), \chi^{2}=3.74$, $\mathrm{p}=0.053 ; \mathrm{OR}=4.89,95 \%$ CI 1.15-20.79, $\mathrm{p}=0.03)$. In history the inflammatory diseases of low genital tract had 11 (44.0 $\%)$ controls and $23(46.0 \%)$ women in the basic group, ovarian cysts $-3(12.0 \%)$ and $5(10.0 \%)$ persons respectively, disorders of menstrual cycle $-7(28.0 \%)$ and 15 $(30.0 \%)$, infertility $-1(4.0 \%)$ and $1(2.0 \%)$, gynecological operations $-2(8.0 \%)$ and $3(6.0 \%)$.

Reproductive anamnesis in controls differs from women with PMS. Only 11 (44.0\%) healthy persons were pregnant versus $35(70.0 \%)$ patients with PMS $\left(\chi^{2}=3.72, \mathrm{p}=0.053\right.$; $\mathrm{OR}=2.97,95 \%$ CI 1.09-8.03, $\mathrm{p}=0.03) .10(40.0 \%)$ of controls had labors versus $32(64.0 \%)$ in basic group $\left(\chi^{2}=2.98\right.$, $\mathrm{p}=0.08 ; \mathrm{OR}=2.67,95 \% \mathrm{CI} 0.99-7.15, \mathrm{p}=0.05)$. There was no significant difference in above mentioned indices between women with mild and severe forms of PMS.

The onset of the first premenstrual symptoms was at the similar age period in both PMS groups $-22.88 \pm 0.99$ years in patients with mild form and $23.04 \pm 1.12$ years - with severe one. Most of the clinical manifestations in women with PMS were connected with psychological (emotional lability, irritability, arousal) and physical disorders (peripheral edema, mastalgia, pain in bones, muscles, lumbalgia). It worth to mention, that all women with PMS declared that manifestations in the second phase of menstrual cycle reduced their daily activities.

Individuals with TC genotype of T-397C polymorphic variant of ESR1 gene were prevalent both in control and basic groups, accounting for about half of all the persons $-52.0 \%$ in control group and $46.0 \%$ in basic one $\left(\chi^{2}=0.06, \mathrm{p}=0.81 ; \mathrm{OR}=0.79,95 \%\right.$ CI $\left.0.30-2.06, \mathrm{p}=0.62\right)$ (table 1). The equal distribution of CC and TT genotypes also was determined between persons without $(24.0 \%$ and $24.0 \%$ respectively) and with PMS (30.0 \% and 24.0 $\%$ respectively). There was no significant difference in the rate of carriers of $\mathrm{T}$ and $\mathrm{C}$ alleles between persons with pathology (70.0 \% and $76.0 \%$ respectively) and without it (76.0\% and $76.0 \%$ respectively). We did not find also significant difference in the frequency of genotypes and alleles between patients with mild and severe forms of the disease. The statistical results of data did not demonstrate the increased risk of T-397C polymorphic variant of ESR1 gene in the development of PMS (table 2).

\section{DISCUSSION}

One of the main pathogenetic mechanisms of PMS development is connected with changes of estrogens and progesterone levels during the menstrual cycle. Estrogens act through the $\alpha$ or $B$ receptors which are genetically encoded by estrogen receptor genes ESR1 and ESR2. The research data about the study of the polymorphism of ESR gene demonstrated its role in the genesis of different pathological diseases. There are reports about its significance as the risk factor in the forming of cancer conditions - cancer of breast [8], endometrium [9], prostate [10], hepatocellular carcinoma [11], etc. However, the meta-analysis in EMBASE, PubMed, CNKI, and 
Table I. The frequency of genotypes and alleles of T-397C variant of ESR1 gene in women with premenstrual syndrome.

\begin{tabular}{ccccc}
\hline Genotype / allele & Control group, $\mathbf{n}=\mathbf{2 5}$ & Mild PMS, $\mathbf{n = 2 5}$ & Severe $\mathbf{P M S , ~} \mathbf{n = 2 5}$ & PMS, total, $\mathbf{n}=\mathbf{5 0}$ \\
\hline TT genotype & $6(24.0)$ & $4(16.0)$ & $8(32.0)$ & $12(24.0)$ \\
\hline TC genotype & $13(52.0)$ & $15(60.0)$ & $8(32.0)$ & $23(46.0)$ \\
\hline CC genotype & $6(24.0)$ & $6(24.0)$ & $9(36.0)$ & $15(30.0)$ \\
\hline T allele & $19(76.0)$ & $19(76.0)$ & $16(64.0)$ & $35(70.0)$ \\
\hline C allele & $19(76.0)$ & $21(84.0)$ & $17(68.0)$ & $38(76.0)$ \\
\hline
\end{tabular}

Table II. Genotypes and alleles of T-397C variant of ESR1 gene as risk factors of premenstrual syndrome.

\begin{tabular}{|c|c|c|c|c|}
\hline Genotype/allele & Indices & Mild PMS, $n=25$ & Severe PMS, $n=25$ & PMS, total, $n=50$ \\
\hline \multirow{3}{*}{ TT genotype } & OR & 0.60 & 1.49 & 1.00 \\
\hline & $\mathrm{Cl}$ & $0.15-2.47$ & $0.43-5.17$ & $0.32-3.08$ \\
\hline & $\mathrm{p}$ & 0.48 & 0.53 & 1.00 \\
\hline \multirow{3}{*}{ TC genotype } & OR & 1.38 & 0.43 & 0.79 \\
\hline & $\mathrm{Cl}$ & $0.45-4.25$ & $0.14-1.37$ & $0.30-2.06$ \\
\hline & $\mathrm{p}$ & 0.57 & 0.16 & 0.62 \\
\hline \multirow{3}{*}{ CC genotype } & OR & 1.00 & 1.78 & 1.36 \\
\hline & $\mathrm{Cl}$ & $0.27-3.67$ & $0.52-6.09$ & $0.45-4.07$ \\
\hline & $\mathrm{p}$ & 1.00 & 0.36 & 0.59 \\
\hline \multirow{3}{*}{ T allele } & OR & 1.00 & 0.56 & 0.74 \\
\hline & $\mathrm{Cl}$ & $0.27-3.67$ & $0.16-1.92$ & $0.25-2.21$ \\
\hline & $\mathrm{p}$ & 1.00 & 0.36 & 0.59 \\
\hline \multirow{3}{*}{ C allele } & OR & 1.66 & 0.67 & 1.00 \\
\hline & $\mathrm{Cl}$ & $0.41-6.78$ & $0.19-2.33$ & $0.32-3.08$ \\
\hline & $\mathrm{p}$ & 0.48 & 0.53 & 1.00 \\
\hline
\end{tabular}

WANFANG systems, in which the literature data were collected till 2018, suggest that ESR1PvuII (rs2234693 $\mathrm{T}>\mathrm{C}$ ) polymorphism may only have little impact on cancer susceptibility [12].

Tang L. et al. studied that persons who have ESR1 PvuII $\mathrm{T}$ allele are in the risk group of hip fracture, while the XbaI polymorphism is not associated with it [13]. Knee osteoarthritis [14], osteoporosis [15] are connected with ESR1 gene polymorphism. The carriers of TC or CC and rs9340799-AG or GG genotype have the highest knee osteoarthritis risk, compared to individuals with rs2228480TT and rs9340799-AA genotype [16].

Pvull and Xbal polymorphisms are associated with premature ovarian rupture [17], while other researches demonstrated opposite results [18]. The risk of infertility can be related to XbaI and PvuII polymorphisms of ESRa in Pakistan population in persons with AG genotype and TC genotype [19]. GG genotype of XbaI polymorphism decrease the risk of preeclampsia, while homozygous T-A haplotype carriers of ESR1 PvuII and XbaI polymorphisms have increased risk [20]. Unexplained spontaneous abortions can be connected with ESR1 polymorphism [21]. There was no the statistically difference in the frequency distribution of the XbaI and of the PvuII genotypes and alleles between the persons with of central precocious puberty and controls. [22].
Also, the meta-analysis reported that PvuII $(\mathrm{C}>\mathrm{T})$ polymorphism was not related to the susceptibility to endometriosis except for a slight association of stage I-III endometriosis under recessive model. This meta-analysis indicated that the PvuII and XbaI polymorphisms were not associated with the risk of endometriosis [23]. Results of meta-analysis which studied the relation between ESR1 gene polymorphism (-351A/G and -397T/C variants) demonstrated the increased risk of severe preeclampsia in the carriers of GG genotype (XbaI -351A/G polymorphism) and no association of the ESR1 gene PvuII $-397 \mathrm{~T} / \mathrm{C}$ and $\mathrm{XbaI}-351 \mathrm{~A} / \mathrm{G}$ polymorphisms with severe and mild preeclampsia [24].

Researches about ESR1 polymorphism as the risk factor of PMS are limited. They mostly are connected with the study of A-351G polymorphic variant. The equal frequency of A/G genotypes between women with and without PMS was found $[25,26]$. Individuals with GG genotype have affective emotional features [25].

\section{CONCLUSIONS}

The study of rate of T-397C variants of estrogen receptor gene ESR1 in patients with PMS was first conducted. There is no association of T-397C polymorphic variant of estrogen receptor gene ESR1 with PMS. 


\section{REFERENCES}

1. Kwan I., Onwude J.L.Premenstrual syndrome. BMJ Clin Evid 2015; 2015: 0806.

2. Tschudin S., Bertea P.C., Zemp E. Prevalence and predictors of premenstrual syndrome and premenstrual dysphoric disorder in a population-based sample. Arch Womens Ment Health. 2010; 13 (6), 485-494. doi: 10.1007/s00737-010-0165-3.

3. Farrokh-Eslamlou H., OshnoueiS., Heshmatian B., Akbari E. Premenstrual syndrome and quality of life in Iranian medical students. Sex Reprod Healthc. 2015;6 (1), 23-27. doi: 10.1016/j.srhc.2014.06.009.

4. Matsumoto T., Asakura H., Hayashi T. Biopsychosocial aspects of premenstrual syndrome and premenstrual dysphoric disorder. Gynecol Endocrino. 2013;29 (1), 67-73. doi: 10.3109/09513590.2012.705383.

5. Toffoletto S., Lanzenberger R., Gingnel M., Sundström-Poromaa I., Comasco E. Emotional and cognitive functional imaging of estrogen and progesterone effects in the female human brain: a systematic review. Psychoneuroendocrinology. 2014; 50, 28-52. doi: 10.1016/j. psyneuen.2014.07.025.

6. Dhingra V., Magnay J.L., O'Brien P.M., Chapman G., Fryer A.A., Ismail K.M. Serotonin receptor $1 A C(-1019)$ G polymorphism associated with premenstrual dysphoric disorder. Obstet Gynecol. 2007;110 (4),788-792.

7. Pro zatverdzhennia klinichnykh protokoliv z akusherskoi ta hinekolohichnoi dopomohy: nakaz M-va okhorony zdorovia Ukrainy № 676 vid 31.12.2004 r. (2014) [Approval of clinical protocols for obstetric and gynecological care]. Available from: https://z-I.com.ua/ ru/new319/\#pms. (In Ukrainian).

8. Zhang Z.L., Zhang C.Z., Li Y., Zhao Z.H., Yang S.E. Association between ERa gene Pvu ll polymorphism and breast cancer susceptibility: A metaanalysis. Medicine (Baltimore). 2018; 97 (17), e0317. doi: 10.1097/ MD.0000000000010317.

9. Zhou X., Gu Y., Wang D.N., Ni S., Yan J. Eight functional polymorphisms in the estrogen receptor 1 gene and endometrial cancer risk: a meta-analysis. PLoS One. 2013; 8 (4), e60851. doi: 10.1371/journal. pone.0060851.

10. Wang Y.M., Liu Z.W., Guo J.B., Wang X.F., Zhao X.X., Zheng X. ESR1 Gene Polymorphisms and Prostate Cancer Risk: A HuGE Review and Meta-Analysis. PLoS One. 2013; 8 (6), e66999. doi: 10.1371/journal. pone.0066999.

11. Sun H., Hou J., Shi W., Zhang L. Estrogen receptor 1 (ESR1) genetic variations in cancer risk: a systematic review and meta-analysis. Clin Res Hepatol Gastroenterol. 2015; 39 (1), 127-135. doi: 10.1016/j. clinre.2014.07.016.

12. Liu X., Huang J., Lin H., Xiong L., Ma Y., Lao H. ESR1 Pvull (rs2234693 $\mathrm{T}>\mathrm{C}$ ) polymorphism and cancer susceptibility: Evidence from 80 studies. Journal of Cancer. 2018; 9(16): 2963-2972. doi: 10.7150/jca.25638.

13. Tang L., Cheng G.L., Xu Z.H. Association between estrogen receptor a gene (ESR1) Pvull (C/T) and Xbal (A/G) polymorphisms and hip fracture risk: evidence from a meta-analysis. PLoS One. 2013; 8 (12), e82806. doi: 10.1371/journal.pone.0082806.

14. Yazdi M.M., Jamalaldini M.H., Sobhan M.R., Jafari M., Mazaheri M., Zare-Shehneh M. et al. Association of ESRa Gene Pvu II T $>C$, Xbal A $>G$ and Btg| $\mathrm{G}>$ A Polymorphisms with Knee 0steoarthritis Susceptibility: A Systematic Review and Meta-Analysis Based on 22 Case-Control Studies. Arch Bone Jt Surg. 2017; 5 (6), 351-362.

15. Shang D.P., Lian H.Y., Fu D.P., Wu J., Hou S.S., Lu J.M. Relationship between estrogen receptor 1 gene polymorphisms and postmenopausal osteoporosis of the spine in Chinese women. Genet Mol Res. 2016; 15 (2). doi: 10.4238/gmr.15028106.
16. Feng Z., Wang C., Sun S. Association of estrogen receptor alpha gene polymorphisms and its gene-gene interactions with knee osteoarthritis susceptibility in Chinese Han population. Int J Clin Exp Pathol. 2017;10(5):5971-5977.

17. Liu L., Tan R., Cui Y., Liu J., Wu J. Estrogen receptor a gene (ESR1) polymorphisms associated with idiopathic premature ovarian failure in Chinese women. Gynecol Endocrinol. 2013; 29 (2), 182-185. doi: 10.3109/09513590.2012.731113.

18. Li J.,Vujovic S., Dalgleish R., Thompson J., Dragojevic-Dikic S., Al-Azzawi F. Lack of association between ESR1 gene polymorphisms and premature ovarian failure in Serbian women. Climacteric. 2014; 17 (3), 247-251. doi: 10.3109/13697137.2013.819330.

19. Liaqat S., Hasnain S., Muzammil S., Hayat S. Polymorphism analysis in estrogen receptor alpha and beta genes and their association with infertile population in Pakistan. EXCLI Journal. 2015;14:1085-1094.doi: 10.17179/excli2015-559.

20. El-Beshbishy H.A., Tawfeek M.A., Al-Azhary N.M., Mariah R.A., Habib F.A., Aljayar L. et al. Estrogen Receptor Alpha (ESR1) Gene Polymorphisms in Pre-eclamptic Saudi Patients. Pak J Med Sci. 2015; 31 (4), 880-885. doi: 10.12669/pjms.314.7541.

21. Pan H., Suo P., Liu C., Wang J., Zhou S., Ma X. et al. The ESR1 gene in unexplained recurrent spontaneous abortion. Syst Biol Reprod Med. 2014; 60 (3), 161-164. doi: 10.3109/19396368.2013.877540.

22. Soares-Jr J.M., de Holanda F.S., Matsuzaki C.N., Sorpreso I.C.E., de Arruda Veiga E.C., de Abreu L.C. et al. Analysis of the Pvull and Xbal polymorphisms in the estrogen receptor alpha gene in girls with central precocious puberty: a pilot study. BMC Medical Genetics (2018) 19:84. doi:10.1186/s12881-018-0577-x.

23. Zhao L., Gu C., Huang K., Fan W., Li L., Ye M. et al. Association between oestrogen receptor alpha (ESR1) gene polymorphisms and endometriosis: a meta-analysis of 24 case-control studies. Reproductive BioMedicine Online. 2016;33, 335-349. doi:10.1016/j.rbmo.2016.06.003.

24. Zhao G., Cai Y., Liu J. Association between the estrogen receptor a gene polymorphisms rs2234693 and rs9340799 and severe and mild preeclampsia: a meta-analysis. Bioscience Reports. 2019;39 BSR20181548. doi: 10.1042/BSR20181548.

25. Aganezova N.V. The role of genetic and hormonal factors in the development of premenstrual syndrome. Zhurnal akusherstva i zhenskih boleznej. 2011; LX (1): 12-20. (In Russian).

26. Pakharenko L. Effect of estrogen receptor gene ESR1 polymorphism on development of premenstrual syndrome. Georgian Med News. 2014; 235, 37-41.

The authors would like to thank the colleges of Department of Medical Genetics, Shupyk National Medical Academy of Postgraduate Education (Kyiv, Ukraine) for help in the research of gene polymorphism.

\section{ORCID and contributionship:}

Lyudmyla V. Pakharenko: 0000-0003-4774-8326 A,D,E,F

Volodymyr D. Vorobii: 0000-0003-2530-5276 ${ }^{D, E}$

Nataliia Ya. Kurtash: 0000-0003-4538-8734 ${ }^{\text {B,E }}$

Olena M. Kusa: 0000-0002-8881-3756 ${ }^{B, C}$

Inna V. Kravchuk: 0000-0003-4550-0415 B,C

Viktor M. Zhurakivskyi: 0000-0002-8628-5507 ${ }^{B, C}$

\section{Conflicts of interest:}

The Authors declare no conflict of interest. 


\section{CORRESPONDING AUTHOR}

Lyudmyla V. Pakharenko

Ivano-Frankivsk National Medical University

106/14 Konovaltsya St., 76014 Ivano-Frankivsk, Ukraine

tel :+038-0974306921,

e-mail:ludapak@ukr.net

Received: 12.08 .2019

Accepted: 09.04.2020

A - Work concept and design, B - Data collection and analysis, C - Responsibility for statistical analysis,

D-Writing the article, $\mathbf{E}$-Critical review, $\mathbf{F}$ - Final approval of the article 